http://journal.nafo.int

J. Northw. Atl. Fish. Sci., Vol. 13: 7-14

\title{
Diurnal Feeding of Juvenile Cod (Gadus morhua) which Migrate into Shallow Water at Night in Eastern Newfoundland
}

\author{
Derek W. Keats \\ Botany Department, University of the Western Cape \\ P. Bag X17, Bellville 7535, South Africa \\ and \\ Donald H. Steele \\ Biology Department, Memorial University of Newfoundland \\ St. John's, Newfoundland, Canada A1B 3X9
}

\begin{abstract}
In Bonavista Bay, Newfoundland, juvenile cod (Gadus morhua) (age-group-0 and -1) were found to move into shallow water at night, where they mostly rested near the bottom. This nocturnal inshore migration was not associated with feeding, as stomach contents data suggested that feeding takes place mainly during the day, with little or no feeding at night. Most prey were planktonic, even in age-group-1 cod. This contrasted with earlier studies in Conception Bay, Newfoundland where age-group-1 cod were mainly obtaining benthic prey. These results suggested that juvenile cod predation on benthic invertebrates was likely to be patchy in space and time. Results are discussed in view of previous knowledge of the dietary and activity patterns of juvenile cod from elsewhere.
\end{abstract}

\section{Introduction}

The inshore waters off Newfoundland probably are important as nursery areas for juvenile cod (Gadus morhua) of the severely depleted LabradorEast Newfoundland cod stock-complex (Lear and Wells, 1984; Keats et al., 1987; Keats, 1990). Despite the economic importance of this stock, and its recent history of over-fishing (Anon., 1992), it is only within the last few years that the ecology and behaviour of juveniles in inshore nursery areas have begun to be studied (Brown et al., 1989; Clark and Green, 1990; Keats et al., 1987, Keats, 1990, Lear et al., MS 1980). Knowledge of the ecology of juvenile cod is of particular importance as it has been suggested that the abundance of juveniles is a good indicator of year-class strength (Campana et al., 1989), and interest has been shown in using the near-shore abundance of juveniles to predict fishery recruitment (Keats, MS 1986; Lear et al., MS 1980).

Keats (1990) documented a nocturnal migration of juvenile cod into shallow water in Bonavista Bay, Newfoundland, but did not determine if the migration was related to feeding. Data presented by Keats et al. (1987) suggest that juvenile cod fed diurnally in Conception Bay, Newfoundland, while European workers have shown that juvenile cod were nocturnal or crepuscular feeders (Arntz, 1973; Pihl, 1982, Zarkeschwari, 1978).
The diet of juvenile cod has been fairly well studied. Most studies have shown that juvenile cod switch from feeding mainly on plankton to feeding mainly on benthic organisms as they change from a pelagic to a demersal existence (Hawkins et al., 1985; Keats et al., 1987, Palsson, 1983, Robb, 1981; Syoseva and Degtereva, 1965). Nevertheless, much can still be learned about variation in the importance of different food items, as well as variation in the potential impact of juvenile cod on the nearshore benthos.

The purpose of the present work is to answer the following questions: Do juvenile cod (age-group1) feed at night when they migrate into shallow water in eastern Newfoundland? What are their main prey types in this area? What is their main source of prey (planktonic, epiphytic or benthic)?

\section{Materials and Methods}

All samples were taken at Newman Sound, Terra Nova National Park, Bonavista Bay, Newfoundland (Fig. 1) between 17 May and 18 August, 1986. Juvenile cod collected during the day were obtained by shooting them with a spear gun through the vertebrae, behind the skull to minimize damage to the otoliths or stomach. All specimens were taken by one diver (DWK) and, by always spearing the fish closest to the diver, care was taken to avoid a size bias. Use of a tremmel net, a shrimp trawl, a 


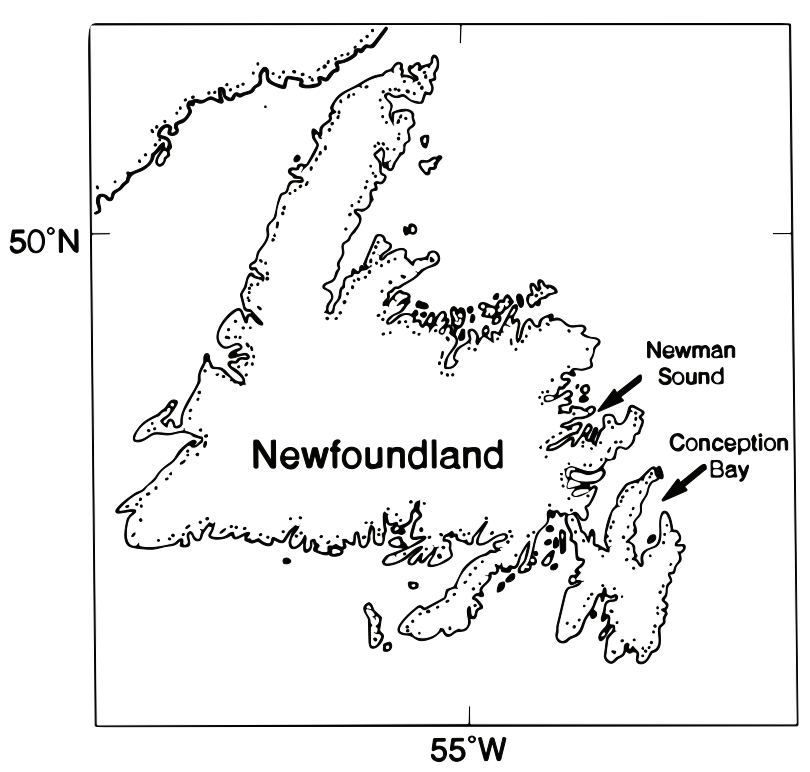

Fig. 1. Map showing the location of the study site at Newman Sound, Bonavista Bay, and Conception Bay, Newfoundland.

beach seine, a small gill net and a hook and line all proved ineffective at catching juvenile cod. The tremmel net quickly filled up with cunners (Tautogolabrus adspersus), the cod could swim faster than we could tow the shrimp trawl, a beach seine cannot be worked on a rocky bottom, and hook and line was swamped with cunners. Spearing such small fish at night is impossible. The small cod are most docile at night, so they were forced to swim into a collecting bag using a diving light to guide them. Any differing size bias which may have been present between the two sampling methods (Table 1 ), were unlikely to affect the conclusion made here, especially since most samples were taken at night.

The following analysis was performed on each fish: fork length was measured to the nearest 1.0 $\mathrm{mm}$, otoliths were removed for age determination,

TABLE 1. Number of juvenile cod collected in different length classes integrated from two sample periods (number in parentheses is $\%$ of total sample for given time period).

\begin{tabular}{ccc}
\hline \hline & \multicolumn{3}{c}{ Time } \\
\cline { 2 - 3 } Length $(\mathrm{cm})$ & 0600-2230 hours & 2300-0430 hours \\
\hline $60-80$ & $7(18)$ & $34(18)$ \\
$85-100$ & $4(11)$ & $64(34)$ \\
$105-120$ & $15(39)$ & $70(37)$ \\
$125-140$ & $10(26)$ & $14(7)$ \\
$145-160$ & $2(5)$ & $6(3)$ \\
Total & 38 & 188 \\
\hline
\end{tabular}

and stomachs were preserved in $70 \%$ ethanol. For age readings, otoliths were broken transversely and examined under either transmitted or reflected light, or both. Stomach contents were examined under a dissecting microscope. A rank scale was used to analyze stomach contents (Keats et al., 1987; Keats and Steele, 1990), because we were primarily interested in determining where the fish obtained their prey, and because of the small size of both the cod stomachs and the prey which they contained. Fullness was estimated on a scale of 0 (empty) to 4 (distended), the degree of digestion on a scale of 1 (fresh) to 4 (well digested remains, identifiable only to general taxonomic groups). Food items were classified into three categories: planktonic (calanoid copepods, carid shrimp zooea, cirriped cyprids, fish eggs and larvae, Oikopleura sp., hyperiid amphipods and medusae), epiphytic (associated with fleshy macroalgae; harpacticoid copepods and several gammarid amphipods) or benthic (found on the bottom rather than on the algae; gastropod molluscs, carid shrimp, bottom-living mysids, several gammarid amphipods, cumaceans and annelids). The classification of food items into the pelagic, epiphytic or benthic categories, are based on personal observations and unpublished studies of the prey taxa. The stomach contents were sorted under a dissecting microscope, and the proportion each food type formed of the total volume was estimated on a scale of 1 to 10. For example, if there were two food types with equal amounts then each was scored as a 5 , but if one type was estimated to be nine times the volume of the other, the former would be scored as 9 and the other as 1 . If only one type of food was found, it was scored as 10. The importance of each type of food was then calculated as the rank of relative volume times the fullness rank of the stomach. Results are expressed both as frequency of occurrence (i.e. percentage of fish containing that type of food), and as importance (i.e. by summing the individual importance values, and calculating the percentage each makes of the total). To examine changes in diet with size, the fish were divided into five size categories $(30-55,56-95,96-125$, 126-165, 166-235 mm), chosen to provide a reasonable number of specimens in each category, and to facilitate comparison with our previous data (Keats et al., 1987).

\section{Results}

\section{Diel feeding pattern}

The limited data available from mid-day suggested that feeding continued throughout the day, so that all measures of total contents were highest in early evening (Fig. 2). Little or no feeding took place at night, as the mean degree of digestion of food in juvenile cod stomachs increased through the night, being greatest in the early morning (Fig. 


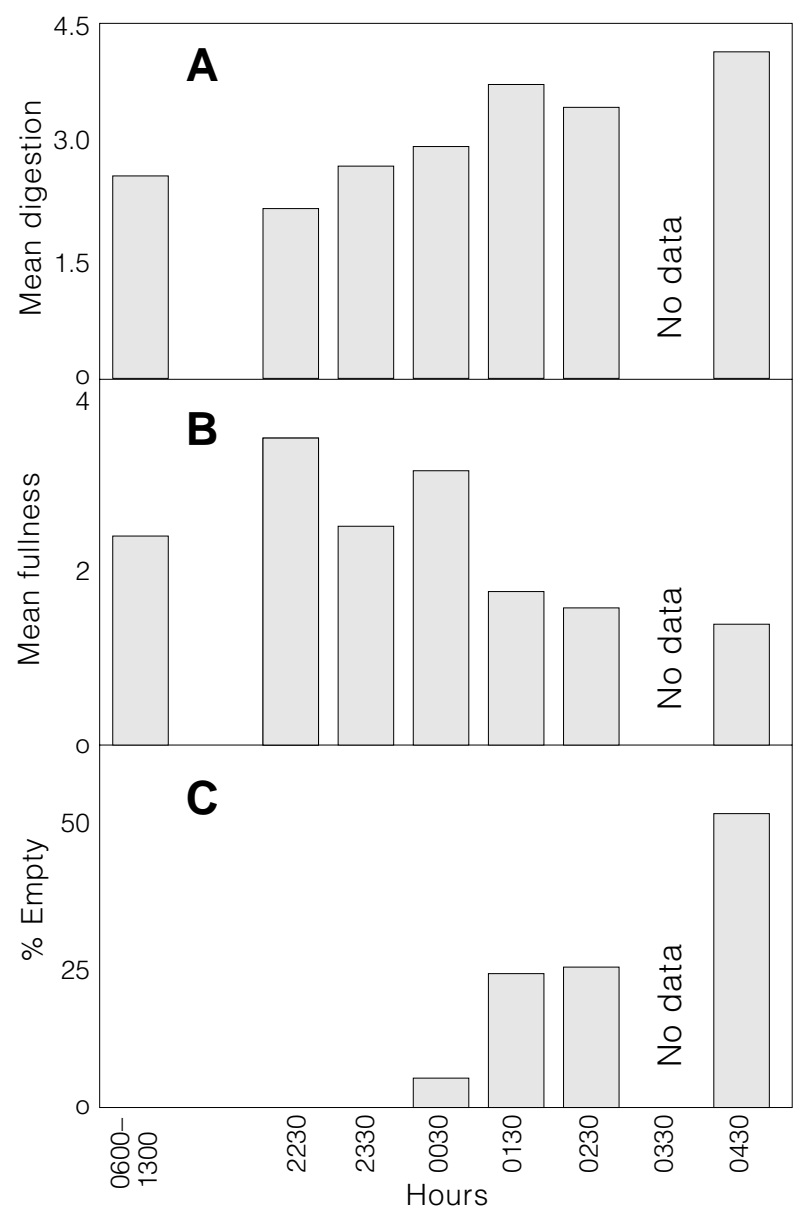

Fig. 2. Mean degree of digestion (A), mean fullness (B), and percent with empty stomachs $(\mathbf{C})$ at different times of the day for juvenile cod from Bonavista Bay, Newfoundland.

2A). The mean volume of stomach contents decreased through the night, and was lowest in the early morning (Fig. 2B). The percentage empty stomachs also increased through the night, being highest in the early morning (Fig. 2C).

\section{Prey type}

Most fish examined contained food (Table 2). Crustaceans were the most important prey in all size groups of cod examined, and calanoid copepods were the most important crustaceans by both percent occurrence (Table 2) and relative importance (Table 3). Amphipods and cyprid larvae had a fairly high incidence of occurrence, but were relatively unimportant overall. The only obvious change in prey type with increasing size was a higher incidence of Oikopleura sp. and medusae in the larger fish. However, this may have been a reflection of the small sample size for the larger individuals. It is unlikely that any significant prey items were missed as there was very little unidentifiable material in the cod stomachs (Table 3).

\section{Prey source}

An analysis of the source of the prey items (i.e. planktonic, epiphytic or benthic) revealed that the juvenile cod of all size groups primarily fed on plankton (Table 4). Of minor importance were epiphytes and benthic prey. A comparison with samples of juvenile cod taken during 1983 in Conception Bay (data from Keats et al., 1987), revealed that the fish sampled in 1986 in Bonavista Bay (in this study) persisted on a pelagic diet to a much greater degree as they grew larger than did fish sampled during the same season in Conception Bay in 1983 (Fig. 3).

\section{Size and growth}

Analysis of the size frequency distributions showed a mode consistently moving to the right indicating that growth occurred throughout the study period (Fig. 4). By late July and early August the first young-of-the-year had appeared. Calculations based on mean size at each time suggested a growth rate of $0.62 \mathrm{~mm}$-per-day for age-group-1 fish in summer.

\section{Discussion}

\section{Time of feeding}

The results presented here strongly suggest that the nocturnal migration into shallow water by juvenile cod (Keats, 1990) does not take place for feeding. Feeding evidently takes place during the daytime, which is consistent with the observations of Keats et al. (1987) in Conception Bay, Newfoundland.

This diurnal feeding, followed by night-time quiescence in shallow water, in the primarily agegroup-1 cod studied here contrasts markedly with the results of sonic tagging studies on older, larger juveniles in Conception Bay (Clark and Green, 1990). Age-group-3 cod were active nocturnally in shallow, warmer water, but rested during the day in deeper, colder water in summer (Clark and Green, 1990). The diel activity pattern of these older juveniles was reversed in autumn, following the breakdown of the thermocline.

Other studies have also suggested that juvenile cod feed at night, rather than during the daytime. Settled age-group-1 cod were reported to rest near the bottom during the day, and to feed in the water column near the bottom at night on Georges Bank (Lough et al., 1989). In Swedish waters individuals 
TABLE 2. Percent occurrence of prey taxa in stomachs of 5 size-groups of juvenile cod from Bonavista Bay.

\begin{tabular}{|c|c|c|c|c|c|}
\hline \multirow[b]{2}{*}{ Taxon } & \multicolumn{5}{|c|}{ Size group (mm) } \\
\hline & $30-55$ & $56-95$ & $96-125$ & $126-165$ & $166-235$ \\
\hline Crustacea & 100 & 96 & 98 & 75 & 29 \\
\hline Harpactacoidea & 30 & 17 & 2 & 0 & 0 \\
\hline Calanoidea & 85 & 89 & 84 & 58 & 14 \\
\hline Shrimp larvae & 25 & 30 & 22 & 25 & 14 \\
\hline Shrimp adults & 0 & 0 & 0 & 5 & 14 \\
\hline Cyprid larvae & 5 & 13 & 16 & 30 & 14 \\
\hline Amphipods & 5 & 14 & 18 & 13 & 0 \\
\hline 1. Ischyrocerus anguipes & 5 & 0 & 1 & 0 & 0 \\
\hline 2. Apherusa megalops & 0 & 2 & 0 & 0 & 0 \\
\hline 3. Bathymedon obtusifrons & 0 & 1 & 1 & 0 & 0 \\
\hline 4. Pontogeneia inermis & 0 & 1 & 2 & 0 & 0 \\
\hline 5. Crophium bonelli & 0 & 4 & 2 & 0 & 0 \\
\hline 6. Calliopius Iaeviusculus & 0 & 0 & 1 & 0 & 0 \\
\hline 7. Photis sp. & 0 & 0 & 1 & 0 & 0 \\
\hline 8. Metopella carinata & 0 & 0 & 2 & 0 & 0 \\
\hline 9. Phoxocephalus inflatus & 0 & 0 & 1 & 0 & 0 \\
\hline 10. Hyperiid amphipods & 0 & 1 & 6 & 8 & 0 \\
\hline Cumacea & 0 & 2 & 3 & 0 & 0 \\
\hline Mysidea & 0 & 0 & 6 & 8 & 14 \\
\hline Gastropoda & 0 & 2 & 0 & 0 & 0 \\
\hline Pteropoda & 0 & 0 & 6 & 5 & 0 \\
\hline Polychaeta & 5 & 4 & 9 & 5 & 0 \\
\hline Fish eggs \& larvae & 5 & 4 & 14 & 5 & 0 \\
\hline Medusae & 0 & 1 & 1 & 8 & 14 \\
\hline Oikopleura sp. & 0 & 2 & 8 & 13 & 43 \\
\hline No. Examined & 24 & 128 & 121 & 24 & 7 \\
\hline$\%$ with food & 96 & 98 & 91 & 100 & 100 \\
\hline
\end{tabular}

in the size range $150-370 \mathrm{~mm}$ fed mainly between dusk and dawn (Pihl, 1982). Data from Kiel Bay, suggested that age-group-0 and -3 cod fed mainly around sunset and sunrise (Arntz, 1973). Pelagic age-group-0 cod fed at night in the northern North Sea (Robb, 1981). These conflicting results suggest a flexibility in diel activity patterns, perhaps related to what Eriksson (1978) has termed "flexibility in fulfilling ecological needs in a semi-opportunistic way".

Whatever the implications of these conflicting results, there is no doubt that the pattern which we observed here is real. Juvenile cod were rarely encountered in shallow water during the daytime, but were found in all habitats sampled at night (Keats, MS 1986; 1990). They were remarkably evenly distributed at night, and the coefficient of variation of transect samples was relatively low (Keats, MS 1986; 1990). Except around sunset when they were arriving in shallow water, and sunrise when they were departing, they were seldom observed to be moving at night if not disturbed (Keats, unpublished observations).

\section{Habitat use}

Studies of diel changes in habitat have also given conflicting results. Juvenile cod (included age-group-0, but mainly age-group-1) were abundant in seaweed beds in the daytime in Conception Bay (Keats et al., 1987). No such strong relationship with algae during the day existed in Newman Sound (Keats, MS 1986), although juvenile cod were occasionally observed in seaweed beds. Juvenile cod were only abundant in shallow water at night in Newman Sound (Keats, 1990). As mentioned, age-group-3 cod seem to spend the day resting in deeper, colder water, and move into shallow water at night (Clark and Green, 1990). The 
TABLE 3. Relative importance of prey taxa in stomachs of 5 sizegroups of juvenile cod from Bonavista Bay.

\begin{tabular}{lrrrrr}
\hline \hline & \multicolumn{5}{c}{ Size group $(\mathrm{mm})$} \\
\cline { 2 - 6 } Taxon & $30-55$ & $56-95$ & $96-125$ & $126-165$ & $166-235$ \\
\hline Crustacea & 99.1 & 95.2 & 83.4 & 87.7 & 22 \\
Harpactacoidea & 10.7 & 6.2 & 0.6 & 0 & 0 \\
Calanoidea & 74.3 & 71.4 & 61.6 & 64.1 & 1.5 \\
Shrimp larvae & 13.0 & 11.1 & 9.2 & 5.8 & 7.5 \\
Shrimp adults & 0 & 0 & 0 & 6.8 & 10.0 \\
Cyprid larvae & 0.4 & 2.1 & 5.8 & 8.6 & 1.5 \\
Amphipods & 0.6 & 3.3 & 2.3 & 0.9 & 0 \\
Cumacea & 0 & 1.1 & 0.6 & 0 & 0 \\
Mysidea & 0 & 0 & 3.2 & 1.5 & 1.5 \\
Gastropoda & 0 & 0.5 & 0 & 0 & 0 \\
Pteropoda & 0 & 0 & 0.7 & 0 & 0 \\
Polychaeta & 0.4 & 1.2 & 4.4 & 0.6 & 0 \\
Fish eggs \& & & & & & \\
larvae & 0.4 & 0.6 & 6.2 & 0.4 & 10.1 \\
Medusae & 0 & 0 & 0 & 1.9 & 20.1 \\
Oikopleura sp. & 0 & 0.7 & 4.3 & 7.5 & 42.7 \\
Unidentifiable & 0 & 1.6 & 1.4 & 2.9 & 5.0 \\
\hline
\end{tabular}

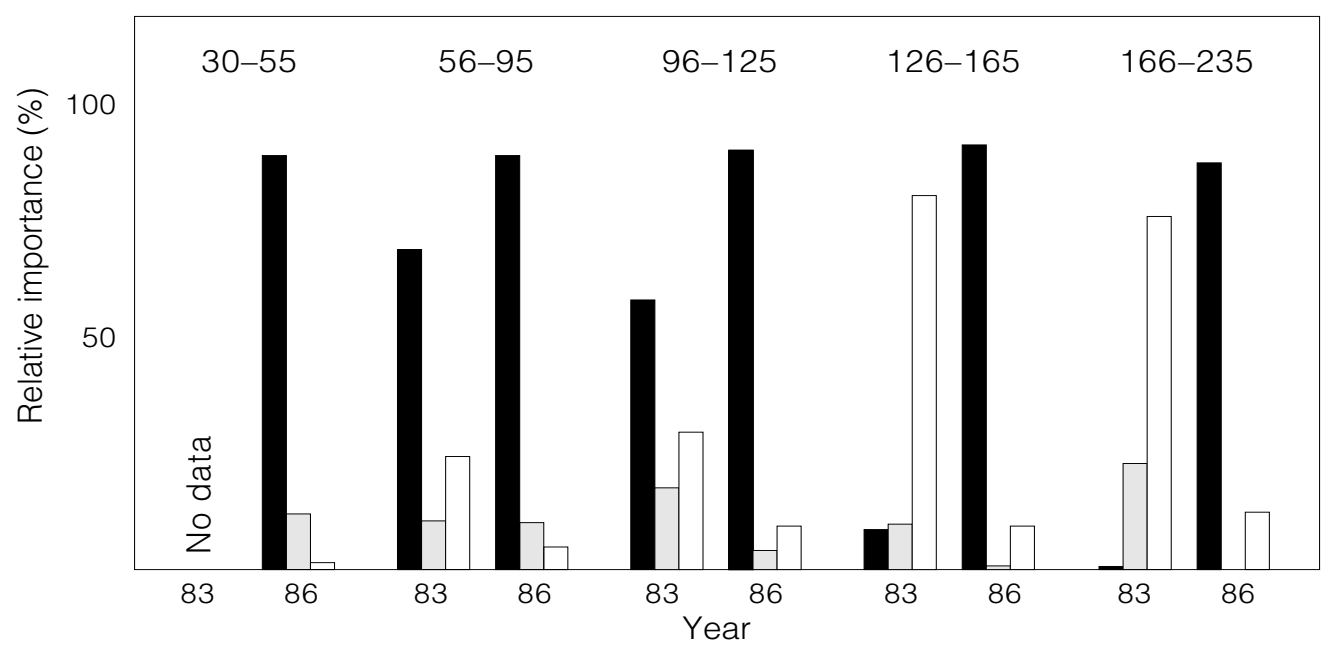

Fig. 3. Relative importance of pelagic (solid), epiphytic (stippled) and benthic (open) prey in the stomachs of juvenile cod from Conception Bay (1983 data from Keats et al., 1987), and Bonavista Bay (1986 data). Numbers above the histograms indicate the size group $(\mathrm{mm})$ of the juvenile cod.

nocturnal feeding at Sweden occurred when the juveniles moved into a shallow bay at dusk, and moved out again at dawn (Pihl, 1982). No diel migration was reported in Kiel Bay (Arntz, 1973; Zarkeschwari, 1978). These observations again suggest flexibility in patterns of habitat use. 
TABLE 4. Percentage importance (calculated form amount $X$ fullness) of pelagic, epiphytic and benthic prey items for each of the 5 sizegroups of juvenile cod examined from Bonavista Bay.

\begin{tabular}{|c|c|c|c|c|c|}
\hline \multirow[b]{2}{*}{ Taxon } & \multicolumn{5}{|c|}{ Size group (mm) } \\
\hline & $30-55$ & $56-95$ & $96-125$ & $126-165$ & $166-235$ \\
\hline \multicolumn{6}{|l|}{ Pelagic } \\
\hline Calanoidea & 74.4 & 73.1 & 62.0 & 62.6 & 1.6 \\
\hline Shrimp larvae & 13.0 & 11.4 & 9.2 & 5.7 & 7.9 \\
\hline Cyprid larvae & 0.4 & 2.2 & 5.8 & 8.4 & 1.6 \\
\hline Hyperiid & & & & & \\
\hline amphipods & 0 & 0.3 & 0.8 & 0.9 & 0 \\
\hline Pteropoda & 0 & 0 & 0.7 & 0 & 0 \\
\hline Fish eggs \& larvae & 0.4 & 0.7 & 6.2 & 0.4 & 10.6 \\
\hline Medusae & 0 & 0 & 0 & 5.1 & 21.2 \\
\hline Oikopleura & 0 & 0.7 & 4.1 & 7.7 & 45.0 \\
\hline Total Pelagic & 88.3 & 88.4 & 88.8 & 90.8 & 87.9 \\
\hline \multicolumn{6}{|l|}{ Epiphytic } \\
\hline Harpactacoida & 10.7 & 6.4 & 0.6 & 0 & 0 \\
\hline Amphipoda & 0.6 & 2.3 & 1.8 & 0.6 & 0 \\
\hline Total epiphytic & 11.3 & 8.7 & 2.4 & 0.6 & 0 \\
\hline \multicolumn{6}{|l|}{ Benthic } \\
\hline Amphipoda & 0 & 0.1 & 0.7 & 0 & 0 \\
\hline Cumacea & 0 & 1.0 & 0.6 & 0 & 0 \\
\hline Mysidae & 0 & 0 & 3.2 & 1.5 & 1.6 \\
\hline Shrimp adults & 0 & 0 & 0 & 6.6 & 10.6 \\
\hline Gastropoda & 0 & 0.5 & 0 & 0 & 0 \\
\hline Polychaeta & 0.4 & 1.0 & 4.3 & 0.6 & 0 \\
\hline Total benthic & 0.4 & 2.6 & 8.8 & 8.7 & 12.2 \\
\hline
\end{tabular}

It is difficult to resolve these conflicting results, although it seems evident that juvenile cod have a flexible diel cycle of feeding activity and habitat utilization. Clark and Green (1990, p. 1435) stated that "whether these differences in behaviour are due to ontogenetic, seasonal and/or population differences is unknown." One possible explanation relates to the possible predation of older stages on younger stages.

Cod are cannibalistic, and larger juveniles (e.g. age-group-3) can feed on smaller juveniles (e.g. age-group-1), and adults can feed on all younger groups (Schroeder, 1930). Given their cannibalistic nature, it would be adaptive for the smaller stages (age-group-0 and -1) to segregate from the larger stages (age-group-3 and -4 , and adults). Furthermore, it would be adaptive for the larger juveniles to segregate from the adults. This segregation could occur in space, by habitat or depth, and in time, by season or time of day. Segregation of cod of different ages is well known. For example, older cod (aged 10-20 years) apparently remain in a very deep water layers which is warmer than the water at intermediate depths (Templeman, 1966). Younger adults and older juveniles evidently overwinter in this deeper water, and move into shallow water in spring. In the inshore area of the southern Gulf of St. Lawrence, groups of cod of adjacent ages were found together consistently from year-to-year (e.g. 2-3, 4-5, 6-8, 9-11 year old groups), but not necessarily in the same geographical area (Tremblay and Sinclair, 1985). Flexibility in this segregation could explain these apparently conflicting results. For the present, however, these ideas must remain in the realm of speculation, and other hypotheses may be equally plausible.

\section{Prey and predation}

All size groups of juvenile cod examined in this study fed primarily on planktonic crustaceans, mainly copepods. This contrasts with the trend of increased benthic feeding with increased size reported from Conception Bay in 1983 (Keats et al., 1987), and from offshore waters of Iceland (Palsson, 1983). The dietary composition of cod is apparently determined largely by availability (Daan, 1978), 


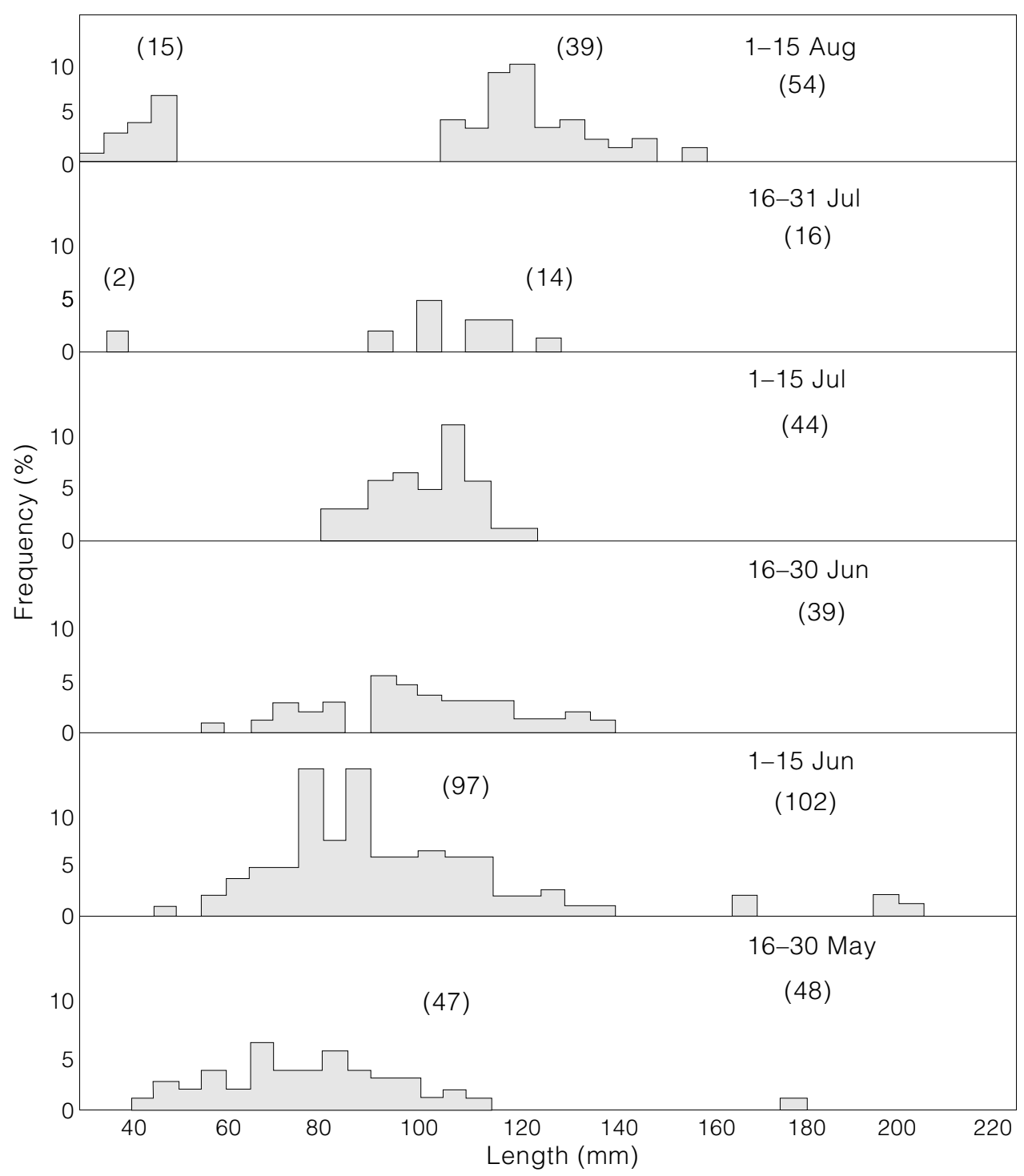

Fig. 4. Size frequency distributions for the juvenile cod sampled from Bonavista Bay, Newfoundland. Numbers in parentheses indicate the number of individuals in each sample.

which could explain these differences. If this is so, then it seems likely that the impact of juvenile cod on small benthic invertebrates would be patchy in space and time. Since juvenile cod are often very abundant, such variable predation on the benthos could contribute to patchiness of benthic invertebrate populations in space and time. This possibility requires experimental evaluation.

\section{Acknowledgements}

We acknowledge Supply and Services Canada, and Fisheries and Oceans Canada for funding this project, and University of the Western Cape (UWC) for funding during manuscript preparation. Terra
Nova National Park, Newfoundland Institute for Cold Ocean Science and Biology Department of Memorial University of Newfoundland, as well as UWC provided facilities and logistic support. K. H. Deichmann and J. Reynolds made all arrangements with Parks Canada. We also thank Gerard Smith and Paul James for diving and technical assistance, and for giving up so many nights sleep. This project would have involved a great deal more personal discomfort were it not for the donation to Memorial University of a Boston Whaler by Charles R. Bell Ltd. Ian Abrahams drafted all figures. G. Keats, K. H. Deichmann and R. Stroud helped tremendously, by running the boat when we wanted to conduct multiple dives. 


\section{References}

ANON. 1992. NAFO Report of the Special Meeting Scientific Council, 1-4 June 1992. NAFO SCS Doc., No. 20, Serial No. N2112, $39 p$

ARNTZ, W. E. 1973. Periodicity of diel food intake of cod Gadus morhua in the Kiel Bay. Oikos Acta Oecol. Scand. (Suppl.), 15: 138-145.

BROWN, J. A., P. PEPIN, D. A. METHVEN, and D. C. SOMERTON. 1989. The feeding, growth and behaviour of juvenile cod Gadus morhua L., in cold environments. J. Fish. Biol., 35: 373-380.

CAMPANA, S. E., K. T. FRANK, C. F. HURLEY, P. A. KOELLER, F. H. PAGE, and P. C. SMITH. 1989. Survival and abundance of young Atlantic cod (Gadus morhua) and haddock (Melanogrammus aeglefinus) as indicators of year-class strength. Can. J. Fish. Aquat. Sci., 46: 171-182.

CLARK, D. S., and J. M. GREEN. 1990. Activity and movement patterns of juvenile Atlantic cod, Gadus morhua, in Conception Bay, Newfoundland as determined by sonic telemetry. Can. J. Zool., 68: 14341442.

DAAN, N. 1978. Changes in cod stocks and cod fisheries in the North Sea. ICES Rapp. Proc.-Verb., 172: 2957

ERIKSSON, L-O. 1978. Nocturnalism versus diurnalism dualism within fish individuals. In: Rhythmic Activity of Fishes. J. E. Thorpe (ed.). Academic Press, London. p. 69-90.

HAWKINS, A. D., N. M. SOOFIANI, and G. W. SMITH. 1985. Growth and feeding of juvenile cod (Gadus morhua L.). ICES J. Cons., 42: 11-32.

KEATS, D. W. MS 1986. A method for the underwater quantification of juvenile cod abundance. CAFSAC Res. Doc., No. 185, 53 p.

1990. A nocturnal inshore movement of juvenile cod Gadus morhua L. in eastern Newfoundland. J. Exp. Mar. Biol. Ecol., 139: 167-173.

KEATS, D. W., and D. H. STEELE. 1990. The fourbeard rockling, Enchelyopus cimbrius (L.), in eastern Newfoundland. J. Fish. Biol., 37: 803-811.

KEATS, D. W., G. R. SOUTH, and D. H. STEELE. 1987. The role of macroalgae in the distribution and feeding of juvenile codfish (Gadus morhua L.) in inshore waters off eastern Newfoundland. Can. J. Zool., 65: 49-53.

LEAR, W. H., and R. WELLS. 1984. Vertebral averages of juvenile cod, Gadus morhua, from coastal waters of eastern Newfoundland and Labrador as indicators of stock origin. J. Northw. Atl. Fish. Sci., 5: 23-31.

LEAR, W. H., A. M. FLEMMING, and R. WELLS. MS 1980. Results of small cod surveys in eastern Newfoundland during 1959-64. NAFO SCR Doc., No. 144, Serial No. N218, $11 \mathrm{p}$

LOUGH, R. G., P. C. VALENTINE, D. C. POTTER, P. J. AUDITORE, G. R. BOLZ, J. D. NEILSON, and R. I PERRY. 1989. Ecology and distribution of juvenile cod and haddock in relation to sediment type and bottom currents on eastern Georges Bank. Mar. Ecol. Prog. Ser., 56: 1-12.

PALSSON, O. K. 1983. The feeding habits of demersal fish species in Icelandic waters. J. Mar. Res. Inst. Reytavik, 7: 1-40.

PIHL, L. 1982. Food intake of young cod and flounder in a shallow bay on the Swedish west coast. Neth. J. Sea Res., 15: 419-432.

ROBB, A. P. 1981. Observations on the food and diel feeding behaviour of pelagic 0-group gadoids in the northern North Sea. J. Fish. Biol., 18: 183-194.

SCHROEDER, W. C. 1930. Migrations and other phases in the life history of cod off southern New England. Fish. Bull. U.S., 46: 1-136.

SYOSEVA, T. K., and A. A. DEGTEREVA. 1965. The relation between the feeding of cod larvae and pelagic fry and the distribution and abundance of their principal food organisms. ICNAF Spec. Publ., 6 : 411-423.

TEMPLEMAN, W. 1966. Marine resources of Newfoundland. Bull. Fish. Res. Board Can., 154: $170 \mathrm{p}$.

TREMBLAY, M. J., and M. SINCLAIR. 1985. Gulf of St. Lawrence cod: age-specific geographic distributions and environmental occurrences from 1971 to 1981. Can. Tech. Rep. Fish. Aquat. Sci., 1387: 43 p.

ZARKESCHWARI, N. 1978. Food composition of cod Gadus morhua L. in shallow waters of Kiel Bay during two 24 hour surveys. Kieler Meeresforschungen Sonderheft, 4: 128-129. 